\title{
Platelets: Mechanistic and Diagnostic Significance in Transplantation
}

\author{
Raneem Khedraki $^{1,2}$ - Jayeeta Dhar ${ }^{1}$. William M. Baldwin III ${ }^{1}$
}

Published online: 25 March 2020

(C) The Author(s) 2020

\begin{abstract}
Purpose of Review In addition to their function in coagulation, platelets recently have been recognized as an important component of innate immune responses. This review relates salient immune functions of platelets to transplants.

Recent Findings Platelets are critical bridges between vascular endothelium and leukocytes. Real-time imaging of platelets has demonstrated that platelets rapidly adhere to vascular endothelium and form a nidus for attachment of neutrophils and then monocytes. However, the majority of platelets subsequently release from endothelium and return to the circulation in an activated state. These recycled platelets have the potential to transport proteins and RNA from the graft to the recipient. Some of the platelets that return to the circulation are attached to leukocytes.

Summary Platelets have the potential to modulate many elements of the graft and the immune response from the time of organ retrieval through ischemia-reperfusion to acute and chronic rejection. Beyond mechanistic considerations, assays that detect changes in platelet protein or RNA expression could be used to monitor early inflammatory responses in transplants.
\end{abstract}

Keywords Innateimmunity $\cdot$ Vascular endothelium $\cdot$ Adhesion molecules $\cdot$ Platelet-leukocyte conjugates $\cdot$ Platelet transcriptome Transplant rejection

\begin{tabular}{|c|c|}
\hline Abbreviations & \\
\hline AMR & Antibody-mediated rejection \\
\hline DSA & Donor-specific antibody \\
\hline GPIb (CD42) & $\begin{array}{l}\text { Glycoprotein } \mathrm{Ib} \text { is a component } \\
\text { of the } G P I b \text {-V-IX complex on } \\
\text { platelets that binds von } \\
\text { Willebrand factor }\end{array}$ \\
\hline $\begin{array}{l}\text { GPIIb/IIIa } \\
\text { (CD41/CD61) }\end{array}$ & $\begin{array}{l}\text { Glycoprotein IIb/IIIa integrin } \\
\text { complex on platelets }\end{array}$ \\
\hline Itga $2 b$ & Gene encoding CD41 \\
\hline Itgb3 & Gene encoding CD61 \\
\hline MCP1 (Ccl2) & $\begin{array}{l}\text { Monocyte chemoattractant } \\
\text { protein } 1\end{array}$ \\
\hline MCP3 (Ccl7) & $\begin{array}{l}\text { Monocyte-chemotactic } \\
\text { protein } 3\end{array}$ \\
\hline
\end{tabular}

This article is part of the Topical Collection on Immunology

William M. Baldwin, III

baldwiw@ccf.org

1 Department of Inflammation and Immunity, Lerner Research Institute, Cleveland Clinic, NB30, 9500 Euclid Ave, Cleveland, OH 44195, USA

2 Biological, Geological, and Environmental Sciences, Cleveland State University, Cleveland, OH, USA

$\begin{array}{ll}\begin{array}{ll}\text { My19 } & \text { Gene encoding myosin } 9 \\ \text { Ppbp (CXCL7) } & \begin{array}{l}\text { Pro-Platelet binding protein } \\ \text { also known as neutrophil- } \\ \text { activating peptide 2 }\end{array} \\ \text { PF4 (CXCL4) } & \begin{array}{l}\text { Platelet factor 4 chemokine } \\ \text { PSGL-1 (CD162) }\end{array} \\ \begin{array}{l}\text { P-Selectin glycoprotein } \\ \text { ligand-1 }\end{array} \\ \text { Serotonin } & \begin{array}{l}\text { Takes up serotonin from } \\ \text { the circulation }\end{array} \\ \text { transporter (SERT) } \\ \text { vWf }\end{array} & \text { von Willebrand factor }\end{array}$

\section{Introduction}

Vascular endothelium is the interface between transplanted organs and the immune response of the recipient. Therefore, endothelial cells are vulnerable to disturbances caused by nonspecific inflammation of ischemic-reperfusion or to antigen specific antibodies or cells. Platelets have evolved to be sensitive monitors of endothelial cell perturbations by virtue of their large numbers and small discoid size. Platelets are 2550 -fold more numerous than leukocytes in the circulation and the fluid dynamics in blood vessels cause the small discoid platelets to flow against the endothelial surface [1]. In spite of their numbers, platelets are inconspicuous in routine histology 
because they contain no nucleus to stain with hematoxylin and little cytoplasm to stain with eosin. However, the cytoplasm of each platelet contains numerous granules with preformed mediators for rapid expression on the plasma membrane or release. These mediators include cytokines, chemokines, adhesion molecules, and growth factors. In addition, upon activation, platelets change shape increasing the surface area for expression of ligands and receptors. These attributes of platelets can be defined by immunohistology using probes that identify steps in platelet activation.

In this review, we will consider a series of interactions between platelets and the transplant progressing from the delivery of mediators through interactions with leukocytes on the endothelium and in the circulation as outlined in Fig. 1.

\section{Platelets Transport Mediators to Graft}

The application of proteomics to platelets has revealed that these small cell fragments contain an unexpectedly wide range of mediators capable of modulating inflammatory and immune responses $[2,3 \bullet]$. In addition, although lacking a nucleus, messenger RNA is incorporated in the cytoplasm of platelets as they fragment from their progenitor megakaryocytes. As discussed later, inflammatory mediators can alter the RNA content of megakaryocytes and newly formed platelets. The RNA is not a vestigial remnant because platelets can splice and translate RNA into protein or transfer the RNA to other cells in inflammatory sites. Therefore, platelets have the potential to modulate many elements of the graft and the immune response from the time of organ retrieval through ischemia-reperfusion to acute and chronic rejection.

Beginning at the time of procurement, immunohistological evaluation of human livers for GPIb (CD42) on platelets has demonstrated that almost one-third of the biopsies have significant numbers of adherent platelets, which were not appreciated by routine histological stains [4]. Moreover, the number of platelets detected in the procurement biopsy predicted the number of adherent neutrophils in a second biopsy taken at the time of reperfusion. This is a potentially treatable variable. We have reported that preserving porcine livers using normothermic machine perfusion compared with static cold preservation decreased platelet aggregation in the vulnerable peribiliary capillary plexus [5].

Small animal experiments designed to probe the response of platelets and neutrophils to ischemia-reperfusion have often
Fig. 1 Platelet interactions with vascular endothelium of the graft and leukocytes of the recipient. a Diagram of platelets transporting mediators, rolling and releasing mediators, tethering and activating leukocytes to the endothelium, releasing to the circulation as conjugates with leukocytes, and transferring protein and RNA systemically. b Immunohistology for CD41 and vWf demonstrating platelets tethering leukocytes to the endothelium (white arrows) and in the circulation as conjugates with leukocytes (black arrows)

\section{a Multifaceted Progression of Platelet Interactions}
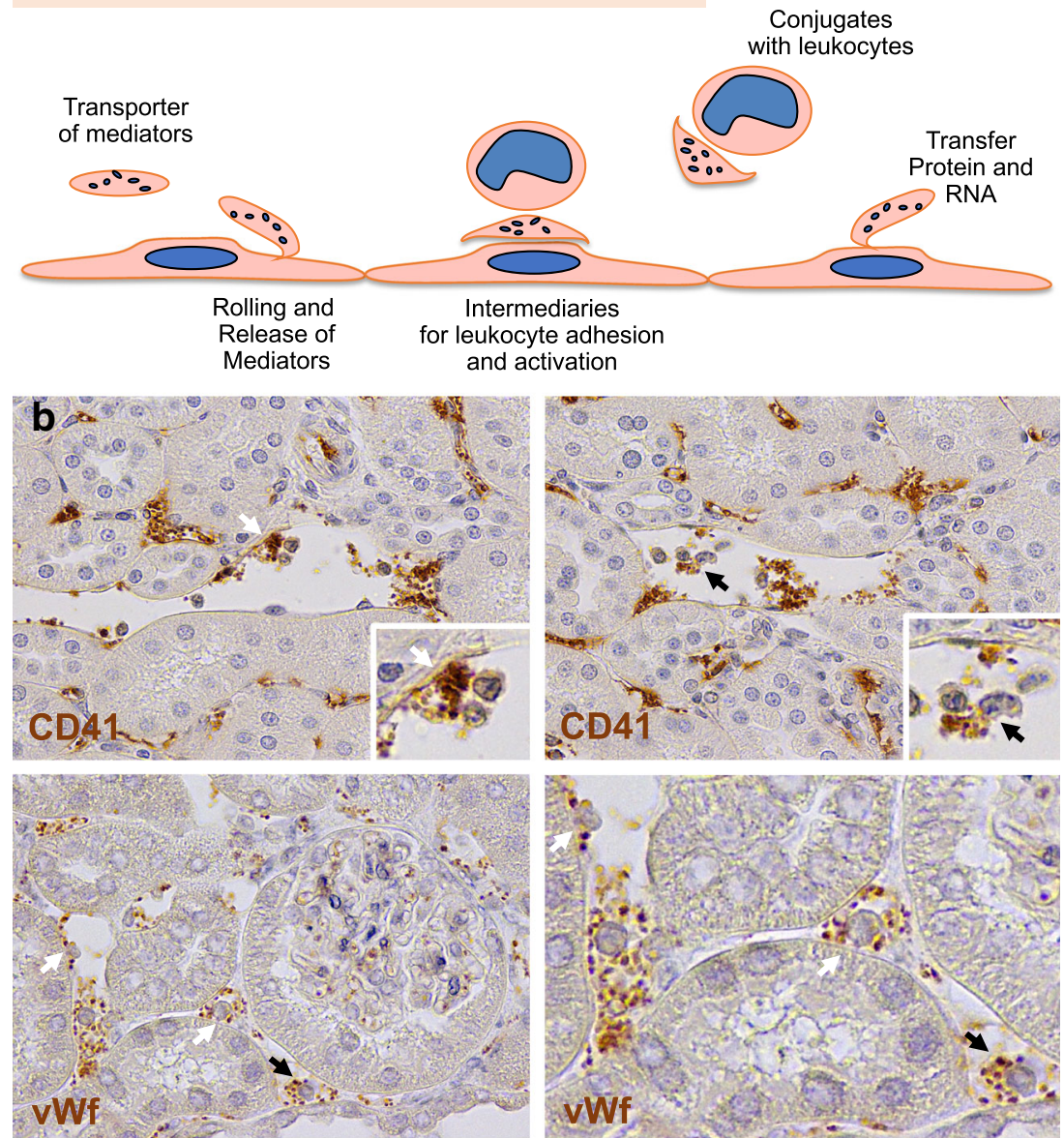
used models of temporary (usually $25-35 \mathrm{~min}$ ) clamping of the organ vessels. However, the warm ischemia caused by clamping organ vessels without flushing blood from the organ by infusing preservation fluid is markedly different from the cold ischemia imposed upon an organ before transplantation. More relevant to transplantation are models that include prolonged cold ischemia times similar to those imposed on deceased donor organs. We have found that cold ischemia times of just $4 \mathrm{~h}$ before renal transplantation in mice results in tubular injury with platelet and neutrophil accumulation in the capillaries particularly at the corticomedullary junction. These platelet aggregates resolve within 2-3 days [6]. Subsequently, as rejection is initiated and progresses, platelets attach to the endothelium $[6,7]$.

In experiments based on transplants to mice in the absence of immunosuppression, grafts elicit both cellular and antibody-mediated rejection (AMR) and both mechanisms cause endothelial injury. Table 1 lists some of the platelet markers that we have found upregulated during rejection of renal and cardiac transplants in mice. We have used a reductionist model to probe the potential involvement of platelets in AMR in the absence of cell-mediated immunity [8]. In this model, an MHC mismatched heart or kidney is transplanted to an immune-deficient $\mathrm{RAG}^{-/-}$recipient. After postoperative inflammation subsides, donor-specific antibodies (DSA) are transferred to the recipients and the immune consequences are monitored. The passive transfer model of AMR is informative because it eliminates the confounding variable of cellmediated injury. Passively transferred DSA results in complement $\mathrm{C} 4 \mathrm{~d}$ deposits on peritubular capillaries and extensive aggregates of activated platelets and macrophages. Although platelets contain hundreds of mediators that could impact inflammation, we found that the transplants accumulate significant concentrations of two mediators - platelet factor 4 (PF4 or CXCL4) and serotonin [8]. These are two of the most highly expressed proteins in platelets [2]. The vasoactive serotonin is not a constitutive component of platelets, but is taken up by platelets through a serotonin transporter (SERT). Plateletderived serotonin has been demonstrated to be critical to extravasation of neutrophils in vascular inflammation $\left[9,10^{\bullet}\right]$. As the name suggests, PF4 is primarily expressed by platelets as well as their progenitor megakaryocytes. Not only is PF4 protein contained in alpha-granules of platelets but mRNA for PF4 is also packaged in the cytoplasm of platelets as they fragment from the megakaryocyte [11].

In ongoing experiments, we have probed renal and cardiac allografts following passive transfer of DSA for 750 RNA targets using the NanoString nCounter platform multiplex analysis. Of the top 6 genes that were upregulated in renal allografts from DSA-treated versus isotype control-treated mice, 4 were platelet-related and included $\mathrm{Cxcl} 4$ (PF4), Ppbp (Pro-Platelet binding protein; CXCL7), Itga2b (CD41), and Itgb3 (CD61). CD41 and Cxcl7 were even more upregulated in heart allografts from DSA-treated versus isotype control-treated mice. P- and E-selectin (Selp and Sele) were also highly upregulated in hearts as well as Ccl2 (MCP1) and Ccl7 (MCP3).

Together, these data offer molecular mechanisms for the histological evidence that platelets interact with neutrophils and monocytes after DSA binds to vascular endothelium (Fig. 1b). CD41/CD61 forms the integrin receptor GPIIb/IIIa that is involved in platelet activation and aggregation. After activation, CD41/CD61 is a receptor for RGD-containing adhesive proteins such as von Willebrand Factor (vWf). The release of vWf from Weibel-Palade storage granules is an acute response of crosslinking MHC molecules on endothelial cells by antibodies in vitro [12], and as Fig. 1b shows, platelets coated with vWf accumulate in capillaries of transplants following passive transfer of DSA in vivo $[8,13]$. Activated platelets also express P-selectin that binds to P-selectin glycoprotein ligand-1 (PSGL-1) on monocytes [14]. Finally, the monocyte chemoattractant proteins 1 and 3 (CCL2 and 7) are critical to transmigration of monocytes through endothelial cells in vitro [15].
Table 1 Platelet-related mediators in transplants

\begin{tabular}{|c|c|}
\hline Protein (gene) & Findings in transplants \\
\hline CxCL7 (Ppbp)* & $\begin{array}{l}\text { Pro-Platelet binding protein also known as neutrophil-activating peptide } 2 \text {; mRNA highly } \\
\text { expressed in platelets and rejecting allografts in mice*** }\end{array}$ \\
\hline CD41 (Itga2b)* & $\begin{array}{l}\text { Glycoprotein IIb component of integrin complex on platelets; mRNA highly expressed in } \\
\text { platelets and rejecting allografts in mice*** }\end{array}$ \\
\hline CD61 (Itgb3)* & $\begin{array}{l}\text { Glycoprotein IIIa component of integrin complex on platelets; mRNA highly expressed in } \\
\text { platelets and rejecting allografts in mice*** }\end{array}$ \\
\hline Myosin 9 (Myl9)* & Cytoskeletal protein in intracapillary platelets and urine in renal allograft models of AMR*** \\
\hline PF4 (Cxc14)* & Chemokine protein in high concentrations in renal allograft models of AMR $* * * *$ \\
\hline Serotonin** & Vasoactive protein in high concentrations in renal allograft models of AMR $* * * * *$ \\
\hline \multicolumn{2}{|c|}{ *mRNA and protein highly expressed in platelets } \\
\hline \multicolumn{2}{|c|}{ **Protein is scavenged into platelets by serotonin transporter (SERT) } \\
\hline$* * * \mathrm{RK}, \mathrm{JD}$, and $\mathrm{W}$ & unpublished observations \\
\hline
\end{tabular}


When platelets adhere to endothelium, they are activated by multiple signals including shear stress that induce release of microvesicles [16]. Activated platelets are the largest source of circulating microvesicles. The proteome of microvesicles from activated platelets has been reported to include the membrane adhesion molecules CD41/CD61 and P-selectin, and the chemokines CXCL4, CXCL7, and CCL5 [17], which overlap with our findings in the passive transfer model of AMR.

The content of microvesicles may contribute to increased release of platelets. Machlus and co-workers [18 ${ }^{\bullet}$ found that CCL5 regulates platelet production by binding to CCR5 on megakaryocytes. Intriguingly, this response can be inhibited in vivo by administering a CCR5 antagonist, maraviroc.

\section{Platelets Tether Leukocytes to Graft}

Intravital microscopy has permitted observation of platelet interactions with endothelial cells and leukocytes in real time. In the cremaster muscle of mice, sterile inflammation induced by TNF $\alpha$ or CCL 2 upregulates vWf expression at the endothelial junctions in small-diameter (about $25 \mu \mathrm{m}$ ) postcapillary venules. This initiates adherence of platelets via GPIIb/IIIb (CD41/CD61). Then, neutrophils attach via CD40 and PSGL-1(CD162) to CD40 ligand (CD154) and Pselectin (CD62P) on the adherent platelets [19•]. Subsequently, monocytes join the attached platelets and neutrophils. Depleting platelets greatly diminishes the interactions of neutrophils and monocytes with the vascular endothelium.

Although the cremaster is a useful model, expression of adhesion molecules differs in different organs and inflammatory signals magnify some of the differences. For example, $\mathrm{TNF} \alpha$ upregulates P-selectin more in the heart than in the kidney, liver, or lung [20]. Even within an organ, endothelial cells in different vascular beds have distinct responses to inflammatory signals. In the kidney, for example, the fenestrated capillary endothelium of the glomerulus does not express Pselectin. As a result, platelets can be even more pivotal in initiating neutrophil arrest. In a model of immune complex glomerulonephritis, neutrophil arrest and release of reactive oxygen species were found to depend on the platelet mediator CXCL7, also known as neutrophil-activating peptide 2 [21•]. This model introduces other critical variables, including antibodies and complement components that can provide additional signals to endothelial cells, platelets, and neutrophils.

We have used intravital microscopy to examine the effects of DSA on platelet interactions with vascular endothelium in skin grafts [22]. Passive transfer of DSA to skin-grafted T cell-deficient mice instigated platelet rolling and arrest in the allograft but not the surrounding skin of the recipient. Immunohistology demonstrated aggregates of platelets associated with vWf in the graft vasculature and with time neutrophil accumulation.
Activated platelets undergo shape change as they interact with endothelium and probe the endothelial surface with "micropods" [8]. These changes in shape require enzymatic cleavage and rearrangement of cytoskeletal proteins. Recently, we discovered that fragments of cytoskeletal proteins are released into the urine in our model of passive transfer of DSA (unpublished observations). A total of 1307 unique proteins were found to be increased in urine from renal transplants after passive transfer of DSA. The proteins identified included the cytoskeletal proteins Talin- 1 and myosin 9 as well as filamin-A, moesin, and tropomyosin. Although these cytoskeletal proteins are widely expressed, they are all abundant in platelets [23]. Immunohistochemistry localized Talin-1 and myosin 9, two cytoskeletal proteins required for shape change, to platelet aggregates in glomerular and peritubular capillaries.

\section{Platelets Form Conjugates with Leukocytes}

Real-time imaging of fluorescently tagged platelets in skin grafts demonstrated the additional important concept that the majority of platelets induced to roll on endothelium by DSA subsequently detach and return to the circulation [22]. As a result, after passive transfer of DSA, an increased number of circulating platelets express P-selectin and have complement split products (C3d) on their surface [22]. P-Selectin is a key adhesion molecule in the coupling of activated platelets to leukocytes to form circulating platelet-leukocyte conjugates. Platelets form conjugates with all types of leukocytes, but platelet P-selectin has the strongest affinity to PSGL-1 on monocytes and neutrophils and lower affinity to lymphocytes [24•]. Circulating platelet-leukocyte conjugates increase in many diseases that involve ischemia, reperfusion, vascular inflammation, or immune complexes [24•]. We have found a high percentage of monocytes and neutrophils in the circulation are conjugated with platelets in experimental models of cardiac and renal allografts. However, the pathological implications of these conjugates remain largely speculative.

\section{Platelets Transfer Protein and RNA}

When platelets break off from megakaryocytes, they contain a wide array of constitutive proteins. Platelets also express a specific transporter to scavenge serotonin from plasma and are the largest source of serotonin in the blood. In addition, platelets take up many proteins through their open canalicular system and by endocytosis $[25,26 \bullet]$. As a result, platelets contain immunoglobulins, complement, and antigens. Importantly for transplantation, platelets have the capacity to upregulate the expression of MHC class I and present antigen 
[27]. Finally, platelets contain small amounts of mRNA derived from megakaryocytes and can synthesize proteins.

The RNA derived from megakaryocytes declines as platelets age. Therefore, inflammatory mediators that either directly or indirectly increase release of platelets from megakaryocytes can alter the RNA signature of circulating platelets. This would include IL- $1 \beta$ and CCL 5 that have been demonstrated to have a direct effect on megakaryocytes and IL-6 that induces the release of thrombopoietin from hepatocytes [18, 28]. A greater effect could result from IL- $1 \alpha$ that causes an accelerated release of platelets through an unusual mechanism of megakaryocyte rupture [29].

Genome-wide RNA-seq analysis has identified a significant overlap in human and mouse platelet transcriptomes [30]. The most highly expressed genes in both human and mouse platelets include Ppbp (CXCL7), Myl9 (myosin 9), Pf4 (CXCL4), Tubb1 (tubulin), and Itga2b (CD41). During inflammation, the RNA content of platelets can be modulated by endogenous and exogenous mechanisms. Three major mechanisms modulate RNA in platelets: (1) specific splicing of pre-mRNAs induced by activation of platelet surface receptors, (2) splice events in response to immune cells and cytokines, and (3) incorporation of mRNA from external sources $[31,32]$. As a result, assays of platelet RNA can be used to monitor inflammation as well as external sources of RNA such as cancer or transplants. Platelets are currently being exploited in "liquid biopsies" as a basis of minimally invasive molecular diagnostics for cancer [33, 34•]. We have tested this concept in by isolating platelets from the circulation of mice with cardiac transplants and found that the expression of Ppbp, Vwf, Itga2b, and Itgb3 increases during rejection (unpublished observations).

\section{Therapeutic Implications}

In addition to their potential as diagnostic indicators of endothelial injury in transplants, platelets are an attractive target for therapeutic intervention during ischemia-reperfusion as well as acute and chronic rejection. Although global depletion of platelets with monoclonal antibodies is a useful experimental approach to determine the contributions of platelets to graft injury $[8,22]$, the increased risk of bleeding limits this as a clinical option. The beneficial effects of platelet inhibitors on atherosclerosis have encouraged the routine use of aspirin in heart transplant patients. One center reported recently that aspirin therapy was associated with decreased chronic allograft vasculopathy and the initiation of aspirin treatment within the first month after transplantation was more beneficial than later treatment [35].

The lungs may be particularly vulnerable to plateletmediated injury. Not only are the alveolar air spaces surrounded by a vast network of capillaries and the airways supported by capillaries but the lungs also contain large numbers of megakaryocytes that produce platelets in the pulmonary microvasculature [36•]. Platelet-monocyte conjugates and soluble P-selectin have been reported to be increased within $6 \mathrm{~h}$ after lung transplantation [37]. Experimentally, clopidogrel, which inhibits platelet aggregation by selectively inhibiting adenosine diphosphate binding to $\mathrm{P}_{2} \mathrm{Y}_{12}$ receptors on platelets, has been found to protect the microvasculature of tracheal transplants [38]. However, drugs such as aspirin and clopidogrel are difficult to manage in transplant recipients [39].

Developing therapeutic interventions include monoclonal antibodies that target domains within adhesion molecules on platelets that interact with specific ligands. For example, GPIb $\alpha$ and vWf undergo multiple conformational changes as their interaction progresses from low to high affinity. Monoclonal antibodies have been developed to epitopes exposed during this progressive interaction that do not alter bleeding time [40]. This new generation of antibodies offers the opportunity to intervene more precisely in platelet interactions with endothelial cells and leukocytes.

\section{Conclusions}

Application of intravital microscopy, proteomics, and genomics to platelets has increased appreciation of the complex interactions these small anucleate cell fragments have in the evolution and resolution of inflammation. It is now clear that these functions are exquisitely responsive to specific conditions and locations. Only limited data are available for the functions of platelets in transplants. It is likely that the responses of platelets differ among the different organs that are transplanted and even within different vascular beds within some organs. However, platelets are emerging as mechanistically and diagnostically relevant to transplantation.

Acknowledgments The authors are grateful for the outstanding immunohistological expertise of Dr. Nina Dvorina.

Funding Information This work was supported by the NIH grant P01AI087586 from the NIAID.

\section{Compliance with Ethical standards}

Conflict of Interest Raneem Khedraki, Jayeeta Dhar, and William Baldwin report the following: This work was supported by the NIH grant P01AI087586 from the NIAID. Dr. Baldwin declares payment as a consultant for Stratatech.

Human and Animal Rights and Informed Consent This article does not contain any studies on human or animal subjects performed by any of the authors. 
Open Access This article is licensed under a Creative Commons Attribution 4.0 International License, which permits use, sharing, adaptation, distribution and reproduction in any medium or format, as long as you give appropriate credit to the original author(s) and the source, provide a link to the Creative Commons licence, and indicate if changes were made. The images or other third party material in this article are included in the article's Creative Commons licence, unless indicated otherwise in a credit line to the material. If material is not included in the article's Creative Commons licence and your intended use is not permitted by statutory regulation or exceeds the permitted use, you will need to obtain permission directly from the copyright holder. To view a copy of this licence, visit http://creativecommons.org/licenses/by/4.0/.

\section{References}

Papers of particular interest, published recently, have been highlighted as:

- Of importance

1. Chang HY, Yazdani A, Li X, Douglas KAA, Mantzoros CS, Karniadakis GE. Quantifying platelet margination in diabetic blood flow. Biophys J. 2018;115(7):1371-82. https://doi.org/10.1016/j. bpj.2018.08.031.

2. Jonnalagadda D, Izu LT, Whiteheart SW. Platelet secretion is kinetically heterogeneous in an agonist-responsive manner. Blood. 2012;120(26):5209-16. https://doi.org/10.1182/blood-2012-07445080.

3. Nassa G, Giurato G, Cimmino G, Rizzo F, Ravo M, Salvati A, et al. Splicing of platelet resident pre-mRNAs upon activation by physiological stimuli results in functionally relevant proteome modifications. Sci Rep. 2018;8(1):498. https://doi.org/10.1038/s41598017-18985-5. Extensive analysis of RNA splicing induced by platelet activation resulting in protein expression.

4. Cywes R, Mullen JB, Stratis MA, Greig PD, Levy GA, Harvey PR, et al. Prediction of the outcome of transplantation in man by platelet adherence in donor liver allografts. Evidence of the importance of prepreservation injury. Transplantation. 1993;56(2):316-23. https:// doi.org/10.1097/00007890-199308000-00011.

5. Liu Q, Nassar A, Farias K, Buccini L, Baldwin W, Mangino M, et al. Sanguineous normothermic machine perfusion improves hemodynamics and biliary epithelial regeneration in donation after cardiac death porcine livers. Liver Transpl. 2014;20(8):987-99. https://doi.org/10.1002/lt.23906.

6. Kohei N, Tanaka T, Tanabe K, Masumori N, Dvorina N, Valujskikh A, et al. Natural killer cells play a critical role in mediating inflammation and graft failure during antibody-mediated rejection of kidney allografts. Kidney Int. 2016;89(6):1293-306. https://doi.org/ 10.1016/j.kint.2016.02.030.

7. Gorbacheva V, Fan R, Beavers A, Fairchild RL, Baldwin WM 3rd, Valujskikh A. Anti-donor MHC class II alloantibody induces glomerular injury in mouse renal allografts subjected to prolonged cold ischemia. J Am Soc Nephrol. 2019;30(12):2413-25. https://doi. org/10.1681/ASN.2018111169.

8. Kuo HH, Fan R, Dvorina N, Chiesa-Vottero A, Baldwin WM 3rd. Platelets in early antibody-mediated rejection of renal transplants. J Am Soc Nephrol. 2015;26(4):855-63. https://doi.org/10.1681/ ASN.2013121289.

9. Cloutier N, Pare A, Farndale RW, Schumacher HR, Nigrovic PA, Lacroix S, et al. Platelets can enhance vascular permeability. Blood. 2012;120(6):1334-43. https://doi.org/10.1182/blood-2012-02413047.
10. Cloutier N, Allaeys I, Marcoux G, Machlus KR, Mailhot B, Zufferey A, et al. Platelets release pathogenic serotonin and return to circulation after immune complex-mediated sequestration. Proc Natl Acad Sci U S A. 2018;115(7):E1550-E9. https://doi.org/10. 1073/pnas.1720553115. These investigators probed one of the important distictions between mouse and human platelets, namely the lack of Fc $\gamma$ RIIA by examining immune complex release of serotonin in transgenic mice that express Fe $\gamma$ RIIA on platelets.

11. Lasagni L, Grepin R, Mazzinghi B, Lazzeri E, Meini C, Sagrinati C, et al. PF-4/CXCL4 and CXCL4L1 exhibit distinct subcellular localization and a differentially regulated mechanism of secretion. Blood. 2007;109(10):4127-34. https://doi.org/10.1182/blood2006-10-052035.

12. Yamakuchi M, Kirkiles-Smith NC, Ferlito M, Cameron SJ, Bao C, Fox-Talbot K, et al. Antibody to human leukocyte antigen triggers endothelial exocytosis. Proc Natl Acad Sci U S A. 2007;104(4): 1301-6. https://doi.org/10.1073/pnas.0602035104.

13. Wasowska BA, Qian Z, Cangello DL, Behrens E, Van Tran K, Layton J, et al. Passive transfer of alloantibodies restores acute cardiac rejection in IgKO mice. Transplantation. 2001;71(6):72736. https://doi.org/10.1097/00007890-200103270-00007.

14. Kuo HH, Morrell CN, Baldwin WM 3rd. Alloantibody induced platelet responses in transplants: potent mediators in small packages. Hum Immunol. 2012;73(12):1233-8. https://doi.org/10. 1016/j.humimm.2012.06.011.

15. Williams MR, Sakurai Y, Zughaier SM, Eskin SG, McIntire LV. Transmigration across activated endothelium induces transcriptional changes, inhibits apoptosis, and decreases antimicrobial protein expression in human monocytes. J Leukoc Biol. 2009;86(6):133143. https://doi.org/10.1189/jlb.0209062.

16. Milioli M, Ibanez-Vea M, Sidoli S, Palmisano G, Careri M, Larsen MR. Quantitative proteomics analysis of platelet-derived microparticles reveals distinct protein signatures when stimulated by different physiological agonists. J Proteome. 2015;121:56-66. https:// doi.org/10.1016/j.jprot.2015.03.013.

17. Garcia BA, Smalley DM, Cho H, Shabanowitz J, Ley K, Hunt DF. The platelet microparticle proteome. J Proteome Res. 2005;4(5): 1516-21. https://doi.org/10.1021/pr0500760.

18. Machlus KR, Johnson KE, Kulenthirarajan R, Forward JA, Tippy MD, Soussou TS, et al. CCL5 derived from platelets increases megakaryocyte proplatelet formation. Blood. 2016;127(7):921-6. https://doi.org/ 10.1182/blood-2015-05-644583. These investigators demonstrate that the release of CCR5 from activated platelets is partly responsible for inflammation-induced thrombocytosis and that this can be blocked in vivo by administering a CCR5 antagonist.

19. Zuchtriegel G, Uhl B, Puhr-Westerheide D, Pornbacher M, Lauber K, Krombach F, et al. Platelets guide leukocytes to their sites of extravasation. PLoS Biol. 2016;14(5):e1002459. https://doi.org/10. 1371/journal.pbio.1002459. Uses intravital microscopy to demonstrate platelet interacting with neutrophils and then monocytes at specific sites in postcapillary venuoles.

20. Molema G. Heterogeneity in endothelial responsiveness to cytokines, molecular causes, and pharmacological consequences. Semin Thromb Hemost. 2010;36(3):246-64. https://doi.org/10. 1055/s-0030-1253448.

21. Finsterbusch M, Norman MU, Hall P, Kitching AR, Hickey MJ. Platelet retention in inflamed glomeruli occurs via selective prolongation of interactions with immune cells. Kidney Int. 2019;95(2): 363-74. https://doi.org/10.1016/j.kint.2018.08.042. Uses intravital microscopy to demonstrate the kinetics of plateletleukocyte interactions induced by imune complexes in the glomerulus.

22. Morrell CN, Murata K, Swaim AM, Mason E, Martin TV, Thompson LE, et al. In vivo platelet-endothelial cell interactions in response to major histocompatibility complex alloantibody. Circ 
Res. 2008;102(7):777-85. https://doi.org/10.1161/ CIRCRESAHA.107.170332.

23. Hartwig JH. The platelet: form and function. Semin Hematol. 2006;43(1 Supp1 1):S94-100. https://doi.org/10.1053/j. seminhematol.2005.11.004.

24. Finsterbusch M, Schrottmaier WC, Kral-Pointner JB, Salzmann M, Assinger A. Measuring and interpreting platelet-leukocyte aggregates. Platelets. 2018;29(7):677-85. https://doi.org/10.1080/ 09537104.2018.1430358. Excellent recent review that discusses and illustrates measurement of platelet-leukocyte conjugates.

25. Zucker-Franklin D. Endocytosis by human platelets: metabolic and freeze-fracture studies. J Cell Biol. 1981;91(3 Pt 1):706-15. https:// doi.org/10.1083/jcb.91.3.706.

26. Selvadurai MV, Hamilton JR. Structure and function of the open canalicular system - the platelet's specialized internal membrane network. Platelets. 2018;29(4):319-25. https://doi.org/10.1080/ 09537104.2018.1431388. A review of our current knowledge of the open canalicular system and its contribution to platelet function.

27. Chapman LM, Aggrey AA, Field DJ, Srivastava K, Ture S, Yui K, et al. Platelets present antigen in the context of MHC class I. J Immunol. 2012;189(2):916-23. https://doi.org/10.4049/jimmunol. 1200580 .

28. Beaulieu LM, Lin E, Mick E, Koupenova M, Weinberg EO, Kramer CD, et al. Interleukin 1 receptor 1 and interleukin 1 beta regulate megakaryocyte maturation, platelet activation, and transcript profile during inflammation in mice and humans. Arterioscler Thromb Vasc Biol. 2014;34(3):552-64. https://doi. org/10.1161/ATVBAHA.113.302700.

29. Nishimura S, Nagasaki M, Kunishima S, Sawaguchi A, Sakata A, Sakaguchi H, et al. IL-1alpha induces thrombopoiesis through megakaryocyte rupture in response to acute platelet needs. J Cell Biol. 2015;209(3):453-66. https://doi.org/10.1083/jcb.201410052.

30. Rowley JW, Oler AJ, Tolley ND, Hunter BN, Low EN, Nix DA, et al. Genome-wide RNA-seq analysis of human and mouse platelet transcriptomes. Blood. 2011;118(14):e101-11. https://doi.org/10. 1182/blood-2011-03-339705.

31. Weyrich AS, Schwertz H, Kraiss LW, Zimmerman GA. Protein synthesis by platelets: historical and new perspectives. J Thromb Haemost. 2009;7(2):241-6. https://doi.org/10.1111/j.1538-7836. 2008.03211.x.
32. Banerjee M, Whiteheart SW. The ins and outs of endocytic trafficking in platelet functions. Curr Opin Hematol. 2017;24(5):467-74. https://doi.org/10.1097/MOH.0000000000000366.

33. Best MG, Sol N, Kooi I, Tannous J, Westerman BA, Rustenburg F, et al. RNA-Seq of tumor-educated platelets enables blood-based pan-cancer, multiclass, and molecular pathway cancer diagnostics. Cancer Cell. 2015;28(5):666-76. https://doi.org/10.1016/j.ccell. 2015.09.018.

34. Best MG, Wesseling P, Wurdinger T. Tumor-educated platelets as a noninvasive biomarker source for cancer detection and progression monitoring. Cancer Res. 2018;78(13):3407-12. https://doi.org/10. 1158/0008-5472.CAN-18-0887. Excellent review of potential diagnostic applications of platelet transcriptome analysis.

35. Peled Y, Lavee J, Raichlin E, Katz M, Arad M, Kassif Y, et al. Early aspirin initiation following heart transplantation is associated with reduced risk of allograft vasculopathy during long-term follow-up. Clin Transplant. 2017;31(12). https://doi.org/10.1111/ctr.13133.

36. Lefrancais E, Ortiz-Munoz G, Caudrillier A, Mallavia B, Liu F, Sayah DM, et al. The lung is a site of platelet biogenesis and a reservoir for haematopoietic progenitors. Nature. 2017;544(7648): 105-9. https://doi.org/10.1038/nature21706. Paradigm shifting report of local platelet production in the lung.

37. Sternberg DI, Shimbo D, Kawut SM, Sarkar J, Hurlitz G, D’Ovidio F, et al. Platelet activation in the postoperative period after lung transplantation. J Thorac Cardiovasc Surg. 2008;135(3):679-84. https://doi.org/10.1016/j.jtcvs.2007.09.058.

38. Heim C, Khan MA, von Silva-Tarouca B, Kuckhahn A, Stamminger T, Ramsperger-Gleixner M, et al. Preservation of microvascular integrity in murine orthotopic tracheal allografts by clopidogrel. Transplantation. 2019;103(5):899-908. https://doi. org/10.1097/TP.0000000000002571.

39. Burlacu A, Genovesi S, Ortiz A, Combe C, Basile C, Schneditz D, et al. Pros and cons of antithrombotic therapy in end-stage kidney disease: a 2019 update. Nephrol Dial Transplant. 2019;34(6):92333. https://doi.org/10.1093/ndt/gfz040.

40. Rana A, Westein E, Niego B, Hagemeyer CE. Shear-dependent platelet aggregation: mechanisms and therapeutic opportunities. Front Cardiovasc Med. 2019;6:141. https://doi.org/10.3389/fcvm. 2019.00141

Publisher's Note Springer Nature remains neutral with regard to jurisdictional claims in published maps and institutional affiliations. 